Periportal and perivenous hepatocytes retain their zonal characteristics in primary culture.

Quistorff, Bjørn; Dich, J.; Grunnet, N.

Published in:

Biochemical and Biophysical Research Communications

Publication date:

1986

Document version

Publisher's PDF, also known as Version of record

Citation for published version (APA):

Quistorff, B., Dich, J., \& Grunnet, N. (1986). Periportal and perivenous hepatocytes retain their zonal

characteristics in primary culture. Biochemical and Biophysical Research Communications, 139(3), 1055-1061. 


\title{
PERIPORTAL AND PERIVENOUS HEPATOCYTES RETAIN THEIR ZONAL CHARACTERISTICS IN PRIMARY CULTURE
}

\author{
B. Quistorff, J. Dich and N. Grunnet \\ Department of Biochemistry $A$, The Panum Institute, \\ University of Copenhagen, Blegdamsvej 3, \\ DK-2200 Copenhagen N, Denmark
}

Received July 22, 1986

Periportal and perivenous hepatocytes from rat liver were isolated by combined digitonin-collagenase perfusion, and gluconeogenesis, urea synthesis and fatty acid synthesis was measured both in freshly isolated cells and in primary culture. A periportal zonation of gluconeogenesis and urea synthesis of about 3 and 1.5 fold, respectively, was observed. This zonation persisted unchanged for 23 hours in culture under identical conditions of incubation for periportal and perivenous cells. Fatty acid syntheSis was not zonated. O 1986 Academic Press, Inc.

The zonation of enzyme activities in the mammalian liver, defined as the ratio of activity in periportal and perivenous cells, has been studied and differences have been found for a number of key enzymes of major metabolic pathways (for recent reviews see (1)). Such data implicate zonation at a functional level of the pathways in question, as demonstrated for glycolysis and gluconeogenesis in microdissection studies (2) and for gluconeogenesis in isolated periportal and perivenous hepatocytes (3) and for urea formation in perfusion studies (4).

Abbreviations: ALAT, alanine aminotransferase; PK, pyruvate kinase; $\overline{\mathrm{PPH}}$, periportal hepatocytes; $\mathrm{PVH}$, perivenous hepatocytes. 
One important question pertaining to the regulatory role of zonation is, however, whether periportal and perivenous hepatocytes remain functionally different when removed from the microcirculation of the liver. In the present paper we have addressed this question with respect to gluconeogenesis, urea formation and fatty acid synthesis in primary culture of hepatocyte preparations enriched in either periportal or perivenous cells (3). Part of this work was presented at (5).

Materials and methods

Hepatocyte suspensions, enriched in either periportal ( $P P H$ ) or perivenous (PVH) hepatocytes, were prepared from 24 hour fasted, $180 \mathrm{~g}$ female wistar rats by collagenase perfusion (6) after selective destruction of either the periportal or the perivenous part of the microcirculation of the liver with digitonin (3).

Cell cultures: Hepatocytes were plated and incubated as described in (7). After 2 hours, the cultures were washed twice with glucose- and serum-free HI-WO/BA medium without hormones. This medium was present for the remaining culture period with added lactate $5 \mathrm{mM}$ and pyruvate $0.5 \mathrm{mM}$. PPH and PVH were incubated under identical conditions. Glucose, urea and fatty acid synthesis was measured in the intervals $2-3,3-4,5-6$ and $22-24$ hours after plating. At the beginning of these time intervals the medium of the dishes was replaced with fresh medium containing tritiated water $(1.5 \mathrm{mCi} / \mathrm{ml})$. I hour later, the incubations were deproteinized by addition of perchloric acid to $0.7 \mathrm{M}$. The perchloric acid precipitate was used for determination of tritium incorporation in lipid fatty acid residues (8) and the supernatant for metabolite determinations after neutralization. In parallel cultures, the medium was replaced by $1.5 \mathrm{ml}$ glycyl-glycin buffer (3) and the cells homogenized by sonication for enzyme activity measurements and DNA determination.

Freshly isolated cells: $1.5 \mathrm{ml} 3-6 \%$ suspensions were incubated in glucose- and serum-free HI-WO/BA medium without hormones under an atmosphere of $\mathrm{O}_{2} / \mathrm{CO}_{2}$ (95/5 vol\%). Lactate $5 \mathrm{mM}$ and pyruvate $0.5 \mathrm{~mm}$ was added. The same procedure as described above was carried out on samples taken after 40 and $80 \mathrm{~min}$ of incubation.

Analyses: The activity of ALAT and PK was measured according to (9), urea, glucose, DNA and protein as described in (9-12), respectively. 


\section{Results}

The technique used for hepatocyte preparation in this study was based on selective destruction by digitonin of either the periportal or the perivenous part of the microcirculation of the liver (3). Thus, the zonal purity of the cells isolated from the remaining part of the liver was determined chiefly by the homogeneity of the flow in the liver during the digitonin destruction. Since the inital fractions of the eluate from the liver after the start of digitonin treatment, must represent cells at the inlet part of the microcirculatory unit periportal or perivenous depending on the direction of flow), the activity of marker enzymes in this eluate may be taken as 'true' periportal or perivenous values. Consequently, it is possible to obtain a measure of the zonal purity of the cell preparation by comparing marker enzyme patterns in the cell preparation with the pattern found in the initial eluate from the same liver. Table I shows such data for ALAT and PK which are marker-enzymes for periportal and perivenous hepatocytes, respectively $(13,14)$. While the eluate shows a periportal/ perivenous ratio of about 6 , this ratio is about 2 in the isolated

Table I. ALAT/PK activity ratios in periportal- and perivenous hepatocytes

\begin{tabular}{|c|c|c|c|c|c|c|c|c|}
\hline & \multicolumn{2}{|c|}{$\begin{array}{l}\text { Perfusion eluates } \\
\text { Sampling interval }\end{array}$} & \multirow[t]{2}{*}{$\begin{array}{c}\text { Freshly isolated } \\
\text { cells }\end{array}$} & \multicolumn{5}{|c|}{$\begin{array}{l}\text { Primary cultures } \\
\text { Time after plating }\end{array}$} \\
\hline & $0-15 \mathrm{sec}$ & $0-30 \mathrm{sec}$ & & $2 \mathrm{~h}$ & $3 \mathrm{~h}$ & $4 \mathrm{~h}$ & $6 \mathrm{~h}$ & $23 \mathrm{~h}$ \\
\hline PPH & $\begin{array}{c}28 \pm 11 \\
(6)\end{array}$ & $\begin{array}{l}37 \pm 9 \\
(6)\end{array}$ & $\begin{array}{r}122 \pm 8 \\
(5)\end{array}$ & $\begin{array}{r}120 \pm 9 \\
(6)\end{array}$ & $\begin{array}{r}122 \pm 7 \\
(6)\end{array}$ & $\begin{array}{c}125 \pm 10 \\
(5)\end{array}$ & $\begin{array}{c}123 \pm 12 \\
(4)\end{array}$ & $\begin{array}{c}120 \pm 11 \\
(5)\end{array}$ \\
\hline PVH & $\begin{array}{c}175 \pm 17 \\
(5)\end{array}$ & $\begin{array}{c}152 \pm 21 \\
(5)\end{array}$ & $\begin{array}{c}73 \pm 5 \\
(5)\end{array}$ & $\begin{array}{c}79 \pm 4 \\
(5)\end{array}$ & $\begin{array}{c}78 \pm 4 \\
(5)\end{array}$ & $\begin{array}{l}75 \pm 4 \\
\text { (5) }\end{array}$ & $\begin{array}{c}76 \pm 4 \\
(5)\end{array}$ & $\begin{array}{l}74 \pm 1 \\
(5)\end{array}$ \\
\hline
\end{tabular}

Periportal- (PPH) and perivenous hepatocytes (PVH) were prepared from $24 \mathrm{~h}$ fasted, female rats by the digitonin-collagenase perfusion technique (3). Prior to cell preparation a liver biopsy was taken. The eluates were sampled $0-15$ and $15-30 \mathrm{sec}$ after digitonin treatment. Alanine aminotransferase (ALAT) and pyruvate kinase (PK) was measured in the biopsy, in the eluate obtained after digitonin perfusion, in the freshly isolated PPH or PVH, and in primary cultures (7) of these cells at the time points indicated. The ALAT/PK ratio is given as $z \pm \mathrm{S} . \mathrm{E}$. of the biopsy value with the number of experiments in parenthesis. The biopsy value for the ALAT/PK ratio was $0.89 \pm 0.07(\mathrm{n}=11)$. All figures are statistically different from the biopsy value, $\mathrm{P}<0.05$. 
cells, indicating that PPH preparations contain approximately $67 \%$ periportal cells and $33 \%$ perivenous cells and vice versa for PVH preparations.

The ALAT/PK activity ratios in freshly isolated cells were identical to those measured in primary culture (Table I) and furthermore remained unchanged over 23 hours of cell culture.

Table II shows data for gluconeogenesis, urea synthesis and fatty acid synthesis. Gluconeogenesis showed an approximately 2 fold periportal zonation in freshly isolated cells as observed previously (3) and a 2-4 fold zonation in cell culture, which remained unchanged for 23 hours. Similarly, urea synthesis showed an approximately 1.5 fold periportal zonation. The zonation of urea formation was also maintained for 23 hours of cell culture, although the absolute rate of urea synthesis decreased by approx-

Table II. Glucose-, urea- and fatty acid synthesis in periportal and perivenous hepatocytes

\begin{tabular}{|c|c|c|c|c|c|c|c|}
\hline & & \multicolumn{4}{|c|}{$\begin{array}{c}\text { Primary cultures } \\
\text { (time after plating) }\end{array}$} & \multicolumn{2}{|c|}{$\begin{array}{l}\text { Freshly isolated cells } \\
\text { (time of incubation) }\end{array}$} \\
\hline & & $2-3 h$ & $3-4 h$ & $5-6 h$ & $22-23 h$ & $0-40 \mathrm{~min}$ & $0-30 \mathrm{~min}$ \\
\hline \multirow{2}{*}{$\Delta$ Glucose } & PPH & $\begin{array}{c}326 \pm 45 * \\
(4)\end{array}$ & $\begin{array}{c}288 \pm 82 \\
(3)\end{array}$ & $\begin{array}{l}289 \pm 48 * \\
(4)\end{array}$ & $\begin{array}{l}466 \pm 90 * \\
\text { (3) }\end{array}$ & $\begin{array}{c}203 \pm 44 * \\
\text { (3) }\end{array}$ & $\begin{array}{c}257 \pm 55 * \\
\text { (4) }\end{array}$ \\
\hline & PVH & $\begin{array}{c}149 \pm 34 \\
(5)\end{array}$ & $\begin{array}{l}76 \pm 26 \\
(6)\end{array}$ & $\begin{array}{c}70 \pm 45 \\
(4)\end{array}$ & $\begin{array}{l}44 \pm 20 \\
(6)\end{array}$ & $\begin{array}{l}85 \pm 18 \\
(5)\end{array}$ & $\begin{array}{c}142 \pm 29 \\
(6)\end{array}$ \\
\hline \multirow{2}{*}{$\Delta$ Urea } & $\mathrm{PPH}$ & $\begin{array}{c}589 \pm 93 * \\
(6)\end{array}$ & $\begin{array}{c}476 \pm 73 \\
(4)\end{array}$ & $\begin{array}{l}560 \pm 18 * \\
(5)\end{array}$ & $\begin{array}{l}418 \pm 54 * \\
(5)\end{array}$ & $\begin{array}{c}442 \pm 24 \text { * } \\
\text { (4) }\end{array}$ & $\begin{array}{c}423 \pm 34 * \\
(5)\end{array}$ \\
\hline & PVH & $\begin{array}{c}370 \pm 30 \\
(5)\end{array}$ & $\begin{array}{c}356 \pm 27 \\
(6)\end{array}$ & $\begin{array}{c}371 \pm 47 \\
(6)\end{array}$ & $\begin{array}{c}241 \pm 64 \\
(6)\end{array}$ & $\begin{array}{c}332 \pm 45 \\
(7)\end{array}$ & $\begin{array}{c}287 \pm 7 \\
(7)\end{array}$ \\
\hline \multirow{2}{*}{$\begin{array}{l}\text { Fatty acid } \\
\text { synthesis }\end{array}$} & $\mathrm{PPH}$ & $\begin{array}{l}73 \pm 10 \\
(4)\end{array}$ & $\begin{array}{l}85 \pm 10 \\
(4)\end{array}$ & $\begin{array}{l}64 \pm 9 \\
(4)\end{array}$ & $\begin{array}{l}24 \pm 6 \\
(4)\end{array}$ & $\begin{array}{c}37 \pm 2 \\
(4)\end{array}$ & $\begin{array}{l}39 \pm 5 \\
(4)\end{array}$ \\
\hline & $\mathrm{PVH}$ & $\begin{array}{l}61 \pm 7 \\
(7)\end{array}$ & $\begin{array}{c}58 \pm 4 \\
(7)\end{array}$ & $\begin{array}{l}47 \pm 8 \\
(7)\end{array}$ & $\begin{array}{c}30 \pm 6 \\
(7)\end{array}$ & $\begin{array}{c}32 \pm 3 \\
(7)\end{array}$ & $\begin{array}{l}34 \pm 4 \\
(7)\end{array}$ \\
\hline
\end{tabular}

Periportal (PPH) and perivenous hepatocytes (PVH) were prepared as indicated in the legend of Table I. Glucose-, urea- and fatty acid synthesis was measured in the intervals indicated for freshly isolated cells and for primary cultures of the same cells. Glucose and urea synthesis is given as nmol per min per mg DNA and fatty acid synthesis as ngatoms ${ }^{3} \mathrm{H}$ per min per mg DNA \pm S.E., with the number of experiments in parenthesis. * indicate $P<0.05$ for PPH versus PVH. 
imately 30 . The observed rate of incorporation of tritiated water in the lipid fraction (Table II) was comparable to previous findings for freshly isolated, fasted hepatocytes (15), but was somewhat higher for the initial 0-4 hour of incubation in cell culture compared with freshly isolated cells. No significant difference in fatty acid synthesis between periportal and perivenous cells was observed in agreement with an even distribution of fatty acid synthase activity along the sinusoid, as demonstrated on microdissected samples (16).

\section{Discussion}

Metabolic zonation has been regarded as a dynamic process, maintained by the gradients of metabolites and hormones along the sinusoids of the liver (1). In the present study we have probed this question by incubating cultures of isolated periportal- and perivenous cells for $0-23$ hours under identical conditions, without the addition of hormones, except for a 2 hour plating period. Under these conditions, we find that the periportal zonation of gluconeogenesis and urea formation of 2-4 and $1.5-2$ fold, respectively, does not change on the 24 hour time scale of the experiment. Addition of hormones, in particular glucagon may, however, cause a disappearance of zonation within this time scale (2). Our data are at variance with those in (17), which suggest that a switching from gluconeogenic to glycolytic cells takes place on a time scale of minutes in the perfused liver upon the switching of the direction of perfusion.

Our results demonstrate that gluconeogenesis and urea synthesis are predominantly periportal processes, as found indirectly in previous studies by cthers $(2,4)$. The estimated zonal purity of the present cell preparations of about $67 \%$ allow calculation of gluconeogenesis and urea formation in 'pure' PPH and PVH. For gluconeogenesis the figures are 450-550 and 0-50 nmol per min per 
mg DNA and for urea formation 550-600 and 250-300 nmol per min per mg DNA, for PPH and PVH respectively. The biological advantage of this co-zonation of gluconeogenesis and urea synthesis is not under stood at present, but may be related to the fact that urea formation with simultaneous gluconeogenesis from alanine, is energetically advantageous compared with gluconeogenesis from pyruvate.

Although a single enzyme of a metabolic pathway can rarely be termed 'rate-limiting' (18), the zonation of the activity of the three pathways measured in the present study, is qualitatively in agreement with the acinar distribution of key enzymes of these pathways.

\section{Acknowledgements}

The authors thank Lissi Immerdal, Marte Nord and Ida Tønnesen for skillfull technical assistance.

\section{$\underline{\text { References }}$}

(1) Thurman, R.G., Kaufman, F.C. and Jungermann, K. (1986) Regulation of Hepatic Metabolism. Plenum Press, New York.

(2) Andersen, B., Nath, A. and Jungermann, K. (1982) Eur. J. Cell. Biol. 28, 47-53.

(3) Quistorff, B. (1985) Biochem. J. 229, 221-226.

(4) Häussinger, D., Sies, H. and Gerok, W. (1984) J. Hepatology $1,3-14$.

(5) Quistorff, B., Dich, J. and Grunnet, N. (1986) Alcohol and Alcoholism 21, (2), Abstract 83 .

(6) Berry, N.M. and Friend, D.S. (1969) J. Cel1. Biol. 43, 506520 .

(7) Dich, J., Bro, B., Grunnet, N., Jensen, F. and Kondrup, J. (1983) Biochem. J. 212, 617-623.

(8) Selmer, J. and Grunnet, N. (1976) Biochim. Biophys. Acta 428, 123-137.

(9) Bergmeyer, H.U. (1974) Methoden der enzymatischen Analyse, 3rd ed., pp 785-791, 800-804. Verlag Chemie, Weinheim/Bergstrasse.

(10) Lowry, O.H. and Passonneau, J.V. (1972) A Flexible system of Enzymatic Analysis, pp 174-175. Academic Press, New York. 
(11) Kissane, J.M. and Robins, E. (1958) J. Biol. Chem. 233, 184188.

(12) Lowry, D.H., Rosebrough, N.J., Farr, A.L. and Randall, R.J. (1951) J. Biol. Chem. 193, 265-275.

(13) Morrison, G.R., Brock, F.E., Karl, I.E. and Shank, R.E. (1965) Arch. Biochem. Biophys. 111, 448-460.

(14) Zierz, S., Katz, N. and Jungermann, K. (1983) Hoppe Seyler's Z. Physiol. Chem. 364, 1447-1453.

(15) Geelen, M.J.H., Lopez-Cardozo, M. and Edmond, J. (1983) FEBS Lett. 163, 269-273.

(16) Katz, N. and Giffhorn, S. (1985) J. Hepatology, suppl. 1, 374.

(17) Matsumura, T. and Thurman, R.G. (1984) Eur. J. Biochem. 140, $229-234$.

(18) Groen, A.K., Wanders, R.J., Westerhoff, H.V., van der Meer, R. and Tager, J.M. (1982) J. Biol. Chem. 257, 2754-2757. 